\title{
CX-4945: the protein kinase CK2 inhibitor and anti-cancer drug shows anti-fungal activity
}

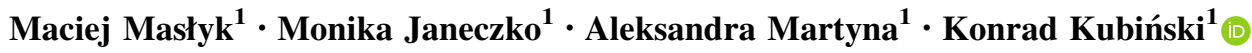

Received: 23 March 2017 / Accepted: 5 May 2017/Published online: 13 May 2017

(c) The Author(s) 2017. This article is an open access publication

\begin{abstract}
CX-4945 is a selective inhibitor of protein kinase CK2 exhibiting clinical significance. Its antitumor properties arise from the abrogation of CK2-mediated prosurvival cellular pathways. The presented data reveal the influence of CX-4945 on the growth of yeast cells showing variable potency against Saccharomyces cerevisiae deletion strains with different contents of CK2 subunits. The catalytic subunit CK2 $\alpha$ appears to sensitize yeast to the CX-4945 action. Moreover, the compound suppresses hyphal growth and cell adhesion of Candida albicans, thereby abolishing some hallmarks of invasiveness of the pathogen. It is known that cancer patients are more prone to fungal infections. Our data unveil the dual-activity of CX-4945; when used in anti-cancer therapy, it may simultaneously prevent cancer-associated candidiasis.
\end{abstract}

Keywords CX-4945 - Protein kinase CK2 - Yeast - Antifungal agents $\cdot$ Antitumor agents

\section{Introduction}

CX-4945 5-(3-chlorophenylamino)benzo[c] [2, 6] naphthyridine-8-carboxylic acid, also known as Silmitasertib, is an ATP- competitive inhibitor of protein kinase CK2. It is a highly selective, orally administered small molecule studied in different types of human cancer research [1]. It has been shown that the mechanism of antitumor activity is

Konrad Kubiński

kubin@kul.pl

1 Department of Molecular Biology, Institute of Biotechnology, The John Paul II Catholic University of Lublin, ul. Konstantynów 1i, 20-708 Lublin, Poland mediated through inhibition of CK2-dependent processes required for maintenance of the phenotype of cancer cells [2]. It has been evidenced that CX-4945 attenuates the PI3K/Akt signaling pathway by suppressing the phosphorylation of Akt and other crucial downstream mediators of the pathway such as p21 [3]. Furthermore, it selectively induces apoptosis in cancer cells and exhibits antiproliferative and anti-angiogenic activity against abnormal cells. CX-4945 exerts its antitumor effects in a wide range of cancer cell types, in which CK2 is overexpressed, such as lung, breast, and prostate cancer cells [2, 3]. Moreover, CX-4945 is the first inhibitor of CK2 that has been qualified for human clinical trials, has successfully completed phase I, and is currently in phase II for cholangiocarcinoma treatment, which granted it an Orphan Drug status for cholangiocarcinoma in the USA in January 2017. Human clinical characterization of CX-4945 as a single agent in solid tumors and multiple myeloma has shown its promising pharmacokinetic, pharmacodynamics, and safety profiles [4]. In addition, besides its antitumor activity, CX4945 may be developed as a new therapeutic agent for pathologies correlated with CK2 dysregulation, such as inflammatory disorders, neurodegenerative diseases, and viral or parasitic infections [5, 6]. Considering all abovementioned characteristics, CX-4945 is assumed to have a significant role in novel therapeutic strategies for treatment of various types of cancer in the future.

CK2 (casein kinase II) is a highly pleiotropic and constitutively active serine/threonine protein kinase regulating a broad spectrum of major cellular processes by reversible phosphorylation of proteins [7, 8]. It appears in a heterotetrameric form, composed of two catalytic subunits ( $\alpha$ and $\left.\alpha^{\prime}\right)$ and two regulatory $\beta$-subunits, or in a monomeric form. Depending on the organism, different isoenzymatic forms of the catalytic subunit of CK2 have been identified [9, 10]. Human CK2 has two well- 
characterized isoforms of the catalytic subunit, designated as CK $2 \alpha$ and CK $2 \alpha$, and a third one, i.e., CK2 $\alpha$ ", which is highly expressed in the liver [11]. Protein kinase CK2 participates in the regulation of a wide array of physiological and pathological processes in the cell, such as cancer development, transcriptional regulation, signal transduction, proliferation, cell cycle control, and apoptosis [12].

Here we present for the first time the influence of CX4945 on single-celled lower eukaryotes-yeast Saccharomyces cerevisiae and Candida albicans. To date, there are many reports describing the role of CK2 in yeast, and the influence of $\mathrm{CK} 2$ has been shown to govern virulence in C. albicans [9, 13-15]. Moreover, an increasing number of reports support the view that there is an association between cancer and fungal infections [16].

\section{Materials and methods}

\section{Microbial strains}

CX-4945 was screened for its in vitro anti-fungal activity against the standard strains: C. albicans ATCC 10231, S. cerevisiae: wild-type strain BMA64-1A, and a deletion mutant lacking CK2 $\alpha$ (YIL035c), and CK2 $\alpha^{\prime}$ (YOR061w). Additionally, CK2 $\alpha$ (YIL035c) was transformed with the shuttle vector $\mathrm{pYES} 2 \mathrm{C} / \mathrm{T}: \mathrm{CKA} 1$.

Microbial susceptibility The yeast strains were inoculated in Sabouraud Dextrose liquid medium (Biocorp, Poland) and incubated at $30{ }^{\circ} \mathrm{C}$ with vigorous shaking (200 rpm) for $24 \mathrm{~h}$ before performing the Minimal Inhibitory Concentration (MIC) and Minimal Fungicidal Concentration (MFC) tests. MIC was determined with the microbroth dilution method. Microbial cell suspensions at initial inoculums of $3 \times 103$ colony forming units per $\mathrm{ml}$ in Sabouraud Dextrose Broth were exposed to the tested compound at adequate concentrations (range $0.001-2 \mathrm{mg} / \mathrm{ml}$ ) for $48 \mathrm{~h}$ at $30{ }^{\circ} \mathrm{C}$. MIC was the lowest concentration of the compound that inhibited the visible growth of the microorganism. After MIC readings, $10 \mu \mathrm{l}$ aliquots were removed from the wells corresponding to MIC, $2 \times \mathrm{MIC}$, and $4 \times \mathrm{MIC}$ and spread on SDA (Sabouraud Dextrose Agar) petri dishes. The plates were incubated at $30{ }^{\circ} \mathrm{C}$ and the fungal colonies grown were counted after approximately 2 days of incubation. The MFC was defined as the lowest drug concentration from which $\leq 1$ colony was visible on the agar plate. The experiments were performed in triplicate.

\section{Hyphal growth of Candida}

The effect of CX-4945 on the hyphal growth of the Candida reference strain was evaluated using Spider medium. Candida cells were grown overnight in Sabouraud broth medium
(Biocorp, Poland) in a shaker at $180 \mathrm{rpm}$ and $37^{\circ} \mathrm{C}$. At the late exponential growth phase, the yeasts cells were harvested using a microcentrifuge (Polygen 1-15PK, Poland) at $2300 \mathrm{~g}$ for $15 \mathrm{~min}$. The yeast cells were washed twice with phosphate buffered saline, $\mathrm{pH} 7.2$, and resuspended in PBS to reach an optical density $\left(\mathrm{OD}_{600}\right)$ of 0.38 (107 cells $\left./ \mathrm{ml}\right)$. $100 \mu \mathrm{l}$ of the suspension containing 107 cells/ml was used for the assays. Candida cells were grown on Spider medium plates containing $10 \%$ fetal bovine serum (FBS), supplemented with or without CX-4945 at the concentration of $\mathrm{MIC} / 10$. The plates were incubated at $37^{\circ} \mathrm{C}$ for $36 \mathrm{~h}$. The morphology of Candida colonies was inspected under a light microscope and imaged using a digital camera.

\section{In vitro biofilm formation assay}

Biofilm assays were performed using a microtiter plate-based method. Sabouraud Dextrose Broth medium (Biocorp, Poland) was used to prepare the bacterial inoculum. To evaluate the effects of the CX-4945 on the initial biofilm formation, the $C$. albicans strain was grown in Saburoud medium in a shaker $(250 \mathrm{rev} / \mathrm{min})$ at $37{ }^{\circ} \mathrm{C}$ for $24 \mathrm{~h}$. Then, the yeast culture was diluted (1:100) in the same medium containing subinhibitory concentrations (1/2 MIC, 1/4 MIC, 1/8 MIC, and 1/16 MIC) of the compound. A volume of $200 \mu \mathrm{l}$ of this mixture was inoculated into each well of a 96-well inert polystyrene microtiter plate. After incubation of the microplate at $37{ }^{\circ} \mathrm{C}$ for $24 \mathrm{~h}$, the supernatants were removed, and the biofilm was washed once with distilled water. It was dried and fixed at $65{ }^{\circ} \mathrm{C}$ for $1 \mathrm{~h}$. Finally, the wells were stained with crystal violet and washed, and the absorbance at $570 \mathrm{~nm}$ was determined using a microplate reader (BIOTEK SYNERGY HT). For examining the possible effects of the compound solvent in biofilm formation, $1 \%$ DMSO was used in the place of the compounds tested in the experiment.

To analyze the effect of the active compound on the mature biofilm, the growth of $C$. albicans biofilm was induced as described above, but in the absence of the compounds, and was incubated for $24 \mathrm{~h}$. Then, the supernatants were gently removed, and the concentrations that were 1/2 MIC, 1/4 MIC, 1/8 MIC, and 1/16 MIC for the compound prepared in Sabouraud broth were added to each well of the microtiter plate. After $24 \mathrm{~h}$ of incubation, the assay was read as described above. All experiments were performed at least three times with four replicates each. $1 \%$ farnesol was used as a positive control.

\section{Results and discussion}

Since CK2 is essential for yeast viability, we verified the possible effect of CX-4945 on S. cerevisiae and C. albicans. The MIC (minimal inhibitory concentration) values 
of 12.5 and $250 \mu \mathrm{g} / \mathrm{ml}$ determined for $S$. cerevisiae and $C$. albicans, respectively, revealed a striking discrepancy between our results and the previously reported $\mathrm{EC}_{50}$ value for human cells [1]. When tested on 43 cancer cell lines, the mean $\mathrm{EC}_{50}$ across all cell lines was $2 \mu \mathrm{g} / \mathrm{ml}(5.5 \mu \mathrm{M})$. The only explanation that arises is the difficulty of CX4945 in penetration of the yeast cell wall. We previously reported that different yeast $\mathrm{CK} 2$ isoforms $\alpha \alpha^{\prime} \beta \beta^{\prime}$, $\alpha^{\prime} \alpha$ ' $\beta \beta^{\prime}, \alpha \alpha \beta \beta$ ', and free catalytic $\alpha$ ' may differ in susceptibility to inhibitors $[17,18]$. We employed two $S$. cerevisiae strains lacking the $\mathrm{CK} 2 \alpha$ or $\mathrm{CK} 2 \alpha$ ' subunit. The MIC values of 125 and $2.5 \mu \mathrm{g} / \mathrm{ml}$ for the $\Delta \alpha$ and $\Delta \alpha$ ' strains, respectively, showed an intriguing difference in their sensitivity towards CX-4945. This clearly shows that the susceptibility of yeast cells to the Silmitasertib action depends on the content of the CK2 subunits and the holoenzyme composition. The transformation of the $\Delta \alpha$ strain with the shuttle vector carrying the gene encoding the $\mathrm{CK} 2 \alpha$ subunit, restoring the native $\mathrm{CK} 2$ content, sensitized the yeast to CX-4945 $(\mathrm{MIC}=1.25 \mu \mathrm{g} / \mathrm{ml})$ (Fig. 1a). Previous in vitro studies on human CK2 isoforms revealed that CX-4945 does not discriminate between different CK2 forms [1, 3]. The compound inhibits the human CK2 holoenzyme as well as free catalytic subunits with the same potency $\left(\mathrm{K}_{\mathrm{i}}=0.38 \mathrm{nM}\right)$. To date, these results have not been verified in in vivo studies.
Besides MIC values, which reflect the influence of the compound on $S$. cerevisiae cell growth, the fungicidal activity of CX-4945 was assayed. The MFC (minimal fungicidal concentration) values of $25,>500$, and $10 \mu \mathrm{g} /$ $\mathrm{ml}$ determined for the wild-type, $\Delta \alpha$, and $\Delta \alpha$ ' strains, respectively, indicate that $\mathrm{CK} 2 \alpha$ sensitizes the yeast cells to the CX-4945 action (Fig. 1b). The most sensitive strain $\Delta \alpha$ ' expresses solely the CK2 $\alpha$ subunit, and thus the cellular CK2 activity is provided only by the holoenzyme $\alpha \alpha \beta \beta$.

In order to verify whether CX-4945 can abrogate cellular functions of $\mathrm{CK} 2$ in yeast, we employed human pathogenic fungus $C$. albicans. Engagement of CK2 in Candida virulence was previously reported [13, 14]. Candida albicans appeared to be more resistant to Silmitasertib in comparison with $S$. cerevisiae, with a MIC value of $250 \mu \mathrm{g} / \mathrm{ml}$. Very recently, we have reported that a natural CK2 inhibitor emodin abrogates hyphal growth of $C$. albicans [19]. In this study, we observed a similar effect in the case of the clinical CK2 inhibitor, where the CX-4945 concentration of 1/10 MIC inhibited yeast-to-hypha transition (Fig. 1c). The phenomenon of hyphal formation is directly involved in Candida-mediated infection [20]. Lo and coworkers showed that mutants that are unable to form hyphae are attenuated in virulence [21]. Another fungal invasion factor is the ability of microorganisms to form

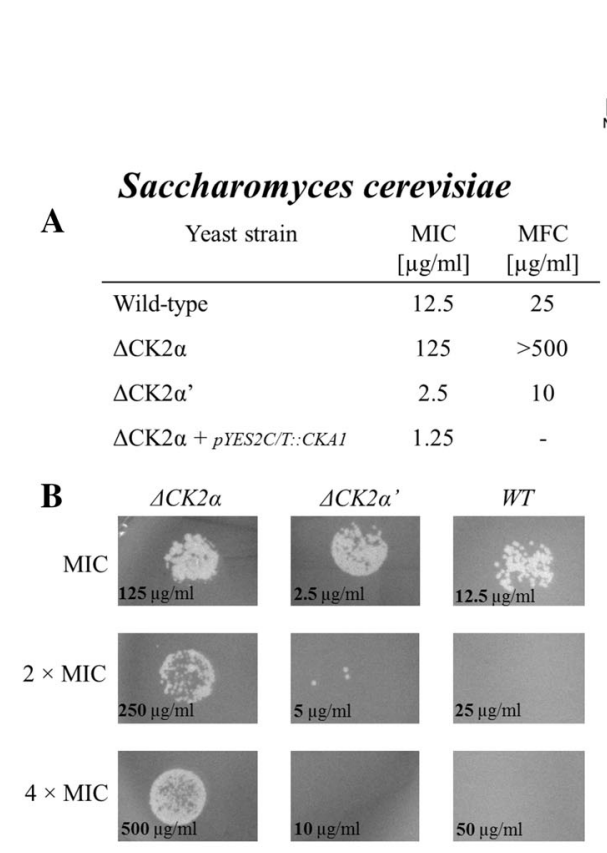

Fig. 1 a MIC values for CX-4945 against $S$. cerevisiae strains, b Macroscopic view of the growth of different $S$. cerevisiae strains. After the MIC assay, the cells from appropriate wells corresponding to MIC, $2 \times \mathrm{MIC}$, and $4 \times \mathrm{MIC}$, were cultured on SDA medium. c Macroscopic view of $C$. albicans colonies grown on agar medium supplemented with FSB (hyphal inductor) and DMSO (control) or
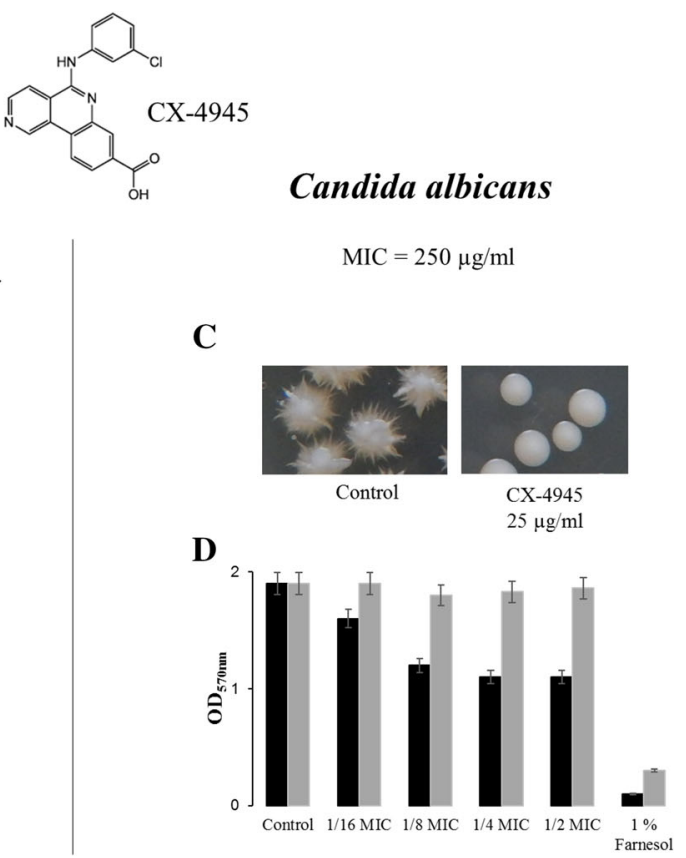

CX-4945. d Effect of CX-4945 on biofilm formation of Candida cells. The black bars indicate the influence of the compound on the adhesion phase during biofilm formation and the gray bars reflect the influence of CX-4945 on established, mature biofilm. Farnesol was used as a positive control 
biofilm, which in its mature form protects the pathogen from antimicrobial agents and host immune factors, and contributes to poor prognosis [22, 23]. Although CX-4945 did not influence mature biofilm, it effectively inhibited the adhesion phase of the biofilm formation process by $42 \%$ at the concentration of $62.5 \mu \mathrm{g} / \mathrm{ml}$ (1/4 MIC) (Fig. 1d).

In summary, the CK2 inhibitor CX-4945 has been recently designated by the U.S. Food and Drug Administration (FDA) as an Orphan Drug for the treatment of cholangiocarcinoma. Our results have shown that the compound inhibits the growth of $S$. cerevisiae discriminating between yeast cell variants carrying different isoforms of protein kinase CK2. Moreover, CX-4945 can suppress the growth of an opportunistic fungal pathogen $C$. albicans. It effectively prevents the fungus from hyphal growth as well as adhesion. Since, the opportunist pathogen takes advantage of the immunosuppressed state of patients, particularly caused by chemotherapy, the application of CX-4945 in targeted chemotherapy may prevent possible cancer-associated candidiasis.

Open Access This article is distributed under the terms of the Creative Commons Attribution 4.0 International License (http://crea tivecommons.org/licenses/by/4.0/), which permits unrestricted use, distribution, and reproduction in any medium, provided you give appropriate credit to the original author(s) and the source, provide a link to the Creative Commons license, and indicate if changes were made.

\section{References}

1. Siddiqui-Jain A, Drygin D, Streiner N, Chua P, Pierre F, O'Brien SE, Bliesath J, Omori M, Huser N, Ho C, Proffitt C, Schwaebe MK, Ryckman DM, Rice WG, Anderes K (2010) CX-4945, an orally bioavailable selective inhibitor of protein kinase CK2, inhibits prosurvival and angiogenic signaling and exhibits antitumor efficacy. Cancer Res 70:10288-10298. doi:10.1158/00085472.CAN-10-1893

2. Manning G, Whyte DB, Martinez R, Hunter T, Sudarsanam S (2002) The protein kinase complement of the human genome. Science 298:1912-1934. doi:10.1126/science.1075762

3. Pierre F, Chua PC, O'Brien SE, Siddiqui-Jain A, Bourbon P, Haddach M, Michaux J, Nagasawa J, Schwaebe MK, Stefan E, Vialettes A, Whitten JP, Chen TK, Darjania L, Stansfield R, Bliesath J, Drygin D, Ho C, Omori M, Proffitt C, Streiner N, Rice WG, Ryckman DM, Anderes K (2011) Pre-clinical characterization of CX-4945, a potent and selective small molecule inhibitor of CK2 for the treatment of cancer. Mol Cell Biochem 356:37-43. doi:10.1007/s11010-011-0956-5

4. Padgett CS, Lim JKC, Marschke RF, Northfelt DW, Andreopoulou E, Von Hoff DD, Anderes K, Ryckman DM, TK C and SE OB (2010) Clinical pharmacokinetics and pharmacodynamics of CX-4945, a novel inhibitor of protein kinase CK2: interim report from the phase 1 clinical trial. 22nd EORTCNCI-AACR symposium on molecular targets and cancer therapeutics, Berlin

5. Drygin D, Ho CB, Omori M, Bliesath J, Proffitt C, Rice R, Siddiqui-Jain A, O'Brien S, Padgett C, Lim JK, Anderes K, Rice WG, Ryckman D (2011) Protein kinase CK2 modulates IL-6 expression in inflammatory breast cancer. Biochem Biophys Res Commun 415:163-167. doi:10.1016/j.bbrc.2011.10.046

6. Guerra B, Issinger OG (2008) Protein kinase CK2 in human diseases. Curr Med Chem 15:1870-1886

7. Krebs EG (1994) The growth of research on protein phosphorylation. Trends Biochem Sci 19:439

8. Meggio F, Pinna LA (2003) One-thousand-and-one substrates of protein kinase CK2? FASEB J 17:349-368. doi:10.1096/fj.020473rev

9. Glover CV (1998) On the physiological role of casein kinase II in Saccharomyces cerevisiae. Prog Nucleic Acid Res Mol Biol 59:95-133

10. Lozeman FJ, Litchfield DW, Piening C, Takio K, Walsh KA, Krebs EG (1990) Isolation and characterization of human cDNA clones encoding the alpha and the alpha' subunits of casein kinase II. Biochemistry 29:8436-8447

11. Shi X, Potvin B, Huang T, Hilgard P, Spray DC, Suadicani SO, Wolkoff AW, Stanley P, Stockert RJ (2001) A novel casein kinase 2 alpha-subunit regulates membrane protein traffic in the human hepatoma cell line HuH-7. J Biol Chem 276:2075-2082. doi:10.1074/jbc.M008583200

12. Litchfield DW (2003) Protein kinase CK2: structure, regulation and role in cellular decisions of life and death. Biochem $\mathrm{J}$ 369:1-15. doi:10.1042/BJ20021469

13. Chiang LY, Sheppard DC, Bruno VM, Mitchell AP, Edwards JE, Filler SG (2007) Candida albicans protein kinase CK2 governs virulence during oropharyngeal candidiasis. Cell Microbiol 9:233-245. doi:10.1111/j.1462-5822.2006.00784.x

14. Konstantinidou N, Morrissey JP (2015) Co-occurence of filamentation defects and impaired biofilms in Candida albicans protein kinase mutants. FEMS Yeast Res. doi:10.1093/femsyr/ fov092

15. Tripodi F, Cirulli C, Reghellin V, Marin O, Brambilla L, Schiappelli MP, Porro D, Vanoni M, Alberghina L, Coccetti P (2010) CK2 activity is modulated by growth rate in Saccharomyces cerevisiae. Biochem Biophys Res Commun 398:44-50. doi:10. 1016/j.bbrc.2010.06.028

16. Ramirez-Garcia A, Rementeria A, Aguirre-Urizar JM, Moragues MD, Antoran A, Pellon A, Abad-Diaz-de-Cerio A, Hernando FL (2016) Candida albicans and cancer: can this yeast induce cancer development or progression? Crit Rev Microbiol 42:181-193. doi:10.3109/1040841X.2014.913004

17. Domańska K, Zieliński R, Kubiński K, Sajnaga E, Masłyk M, Bretner M, Szyszka R (2005) Different properties of four molecular forms of protein kinase CK2 from Saccharomyces cerevisiae. Acta Biochim Pol 52:947-951

18. Sajnaga E, Kubiński K, Szyszka R (2008) Catalytic activity of mutants of yeast protein kinase CK2alpha. Acta Biochim Pol 55:767-776

19. Janeczko M, Masłyk M, Kubiński K, Golczyk H (2017) Emodin, a natural inhibitor of protein kinase CK2, suppresses growth, hyphal development, and biofilm formation of Candida albicans. Yeast. doi:10.1002/yea.3230

20. Mayer FL, Wilson D, Hube B (2013) Candida albicans pathogenicity mechanisms. Virulence 4:119-128. doi:10.4161/ viru. 22913

21. Lo HJ, Köhler JR, DiDomenico B, Loebenberg D, Cacciapuoti A, Fink GR (1997) Nonfilamentous C. albicans mutants are avirulent. Cell 90:939-949

22. Fanning S, Mitchell AP (2012) Fungal biofilms. PLoS Pathog 8:e1002585. doi:10.1371/journal.ppat.1002585

23. Hasan F, Xess I, Wang X, Jain N, Fries BC (2009) Biofilm formation in clinical Candida isolates and its association with virulence. Microbes Infect 11:753-761. doi:10.1016/j.micinf.2009. 04.018 